\title{
Vztah životní spokojenosti a jejích složek s osobnostními charakteristikami u studentů učitelských oborů
}

\section{Lucie Křeménková, Jana Kvintová, Michaela Pugnerová}

\begin{abstract}
Abstrakt
Cílem příspěvku byla analýza životní spokojenosti ve vazbě na osobnostní charakteristiky studentů učitelských oborů. Výzkumného šetření realizovaného dotazníkovými metodami (DŽS, NEO-PI-R) se zúčastnilo celkem 319 respondentů. V rámci výsledků byla u studentů učitelských oborů zjištěna výrazně nižší míra spokojenosti se zdravím a vlastní osobou, než jsou normativní hodnoty stejně staré populace, dále nebyla neprokázána souvislost životní spokojenosti s věkem $(r=-0,008)$ ani s pohlavím $(r=0,02)$. Naopak byly potvrzeny výzkumné předpoklady mapující souvislosti mezi životní spokojeností a osobností. Konkrétně se potvrdila vazba mezi životní spokojeností a emoční stabilitou $(r=-0,49)$, extraverzí $(r=0,37)$, prívětivostí $(r=0,3)$ a svědomitostí $(r=0,23)$. Souvislost životní spokojenosti s otevřeností vůči novým zkušenostem $(r=0,04)$ nebyla prokázána.
\end{abstract}

Klíčová slova: životní spokojenost, osobní pohoda, osobnostní rysy, student, učitelské obory.

\footnotetext{
Abstract

The aim of the paper was to analyze the life satisfaction in relation to personality characteristics of students of teaching disciplines. The research survey was performed by
} 
questionnaire methods (DZS, NEO-PI-R) and comprised 319 participants. As part of the results has been found significantly lower levels of satisfaction with Health and Self by the students of teaching fields than the normative values of the same age population. It has not been found continuity of Life satisfaction with age $(r=-0.008)$, nor with sex $(r=0.02)$. Conversely, it have been confirmed the research assumption mapping relation between Life satisfaction and Personality. Specifically, it has been confirmed a link between Life satisfaction and Neuroticism ( $r=-0.49)$, Extraversion (0.37), Agreeableness $(r=0.3)$ and Conscientiousness $(r=0.23)$. Life satisfaction relationship with Openness to experiences $(r=0.04)$ has not been proved.

Keywords: Personality Traits, Life Satisfaction, Well-being, Student, Educational fields of study.

\section{Uvedení do problematiky}

Studenti učitelských oborů jsou specifickou skupinou vysokoškolských studentů. Vzhledem k povaze studia a především pak jejich následné profesi, Ize považovat za žádoucí a př́nosné sledovat míru jejich životní spokojenosti, osobnostní charakteristiky i jejich vzájemné souvislosti. Analýza životní spokojenosti učitelů (respektive budoucích učitelů) je žádoucí z několika důvodů: a) existuje pozitivní souvislost mezi životní spokojeností učitelů a kvalitním vzděláváním studentů, profesním výkonem a dalšími aspekty efektivní výuky (Baker \& Martin, 2009; Spilt et al., 2011), b) spokojený učitel má pozitivní vliv na klima třídy (Noddings, 2005; Baker \& Martin, 2009), c) spokojený učitel je ve své profesi kreativnější, ochotněji se podílí na zavádění nových výukových postupů a zaujímá pozitivnější postoje vůči školským reformám, různým intervenčním programům a škole jako takové (van Veen et al. 2005; Huang, 2005; Spilt et al., 2011), d) spokojený učitel efektivněji podporuje rozvoj autentických lidských vztahů s žáky a mezi žáky (Muijs \& Reynolds, 2005). Podobně jako v případě životní spokojenosti je u budoucích učitelů podstatné analyzovat osobnostní charakteristiky, které jsou pro výkon učitelské profese zcela zásadní. Osobnost ovlivňuje v různé míre v zásadě všechny psychické procesy a stavy a má rovněž nezanedbatelný vliv i na již zmiňovanou životní spokojenost (viz dále). Významné role psychologické skladby osobnosti učitele si všímá řada odborníků (srv. např. Darling-Hammond, 1999; Ripski, LoCasale-Crouch \& Decker, 2011; Thornton, 2006; Yuan, Aman, 2016), kteří poukazují na fakt, že při pregraduální prípravě učitele není podstatné zaměřovat se pouze na způsoby výuky, hodnocení žáků a další pedagogické oblasti, ale i na osobnost učitele a její rozvoj (Wenzlaff, 1998).

Vzhledem $\mathrm{k}$ tomu, že učitelské profesi je dlouhodobě věnována pozornost především v oblastech stresu a syndromu vyhoření, považujeme za důležité upozornit i na další jevy, které hrají v jejím kvalitním naplňování důležitou roli a zároveň i upřít 
pozornost na kategorii studentů učitelských oborů, u kterých je v rámci pregraduálního studia možné věnovat pozornost takovým postupům a metodám v rámci psychologických disciplín, které by jim umožnily, případně usnadnili vyrovnat se s úskalími učitelské profese, ale i života jako takového a snadněji nacházet a udržet životní spokojenost.

\section{Koncept životní spokojenosti}

Koncept životní spokojenosti je interdisciplinární konstrukt, který kromě psychologie, kde je úzce spjat se směrem pozitivní psychologie, zasahuje i do dalších vědních oborů. Podobně jako řada jiných psychologických termínů je provázen řadou formulačních nejasností a nejednoznačným koncepčním ukotvením. V zahraničí se Ize nejčastěji setkat s termíny „,well-being“ (případně „,subjective“, „,psychological”, nebo „mental“" well-being), „life satisfaction“, „,welfare“, ,„pleasure“, ,,prosperity“, prípadně „,happiness“. V českém prostředí pak bývají, kromě již ustáleného termínu well-being, nejvíce používány pojmy „pohoda“ (případně „duševní pohoda“, nebo „pocit či prožitek osobní pohody“), ,„životní

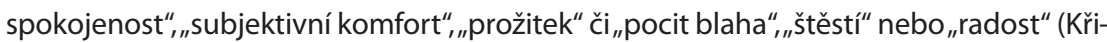
vohlavý, 2001; Mareš, 2001; Kebza \& Šolcová, 2005; Řehulková \& Řehulka, 2008). Celkově však mezi odborníky panuje v zásadě shoda v tom, že ačkoliv uvedené pojmy nejsou skutečná synonyma, jsou si obsahově blízké, přičemž dochází k jejich vzájemnému přesahování' (Blatný, 2005). V kontextu našeho příspěvku i vzhledem k použité metodě (viz dále) budeme používat spojení „životní spokojenost".

Životní spokojenost je pojímána jako součást širšího konceptu (často označovaného jako „osobní pohoda“), který dále zahrnuje také afektivní složku (Diener, 1984, 2000; Blatný, 2001, 2005; Kebza \& Šolcová, 2005). Životní spokojenost pak v tomto modelu znázorňuje kognitivní složku, jež představuje vědomé, globální hodnocení vlastního života a také spokojenost v důležitých životních oblastech (např. práce, rodina, přátelé apod.) (Diener, 2000). Ukazuje se, že z uvedených konstruktů má životní spokojenost ke konceptu osobní pohody významově nejblíže, což dokládá fakt, že životní spokojenost je nejčastější výzkumnou operacionalizací osobní pohody (DeNeveová \& Cooper, 1998; Blatný, 2005). V současné době se koncepty popisující životní spokojenost zaměřují převážně na subjektivní vnímání a hodnocení vlastního života (Diener, et al., 1997; Diener, 2000; Blatný, 2005). Jinými slovy je spokojenost se životem založena na individuálních, konkrétních představách, hodnotách, postojích, nadějích, očekávání, cílech, přičemž vše může podléhat a měnit se v průběhu času a vlivem vnitřních i vnějších podmínek (Křivohlavý, 2001; Hamplová, 2004).

\footnotetext{
1 V konkrétních teoriích pak většinou jeden z pojmů vytvoří zastřešující koncept (často např. osobní pohoda) a zbylé pojmy se stávají jeho součástí (životní spokojenost, pozitivní a negativní emoční stavy, štěstí, sebehodnocení) (Blatný, 2005).
} 


\subsection{Vztah životní spokojenosti k vybraným demografickým proměnným}

Při hledání souvislostí mezi věkem a životní spokojeností se ukazují spíše rozporuplné výsledky. Obecně však Ize soudit, že spokojenost v různých oblastech života se s věkem vyvíjí rozdílně. S postupujícím věkem se tedy bude pravděpodobně snižovat spokojenost se zdravotním stavem, s finančními poměry či sexualitou. Ve střední dospělosti Ize očekávat vyšší spokojenost s finanční situací, vztahem k vlastní osobě i s rodinným zázemím. Celkově však výsledky, s jistou mírou opatrnosti, spíše poukazují na trend směřující k vyšší spokojenosti s přibývajícím věkem (Ryff, \& Keyes, 1995; Fahrenberg, et al., 2001).V př́padě závislosti životní spokojenosti na pohlaví jsou výsledky více jednoznačné, přičemž se ukazuje, že vliv pohlaví na celkovou životní spokojenost je spíše nepatrný (Fahrenberg, et al., 2001), nicméně některé studie naznačují, že nepatrně vyšší životní spokojenost Ize nalézt u žen (srov. např. Wood et al., 1989; Boarini et al., 2012).

\section{2 Životní spokojenost a osobnost}

Životní spokojenost je výslednicí interakce mezi vnitřními a vnějšími faktory. Osobnostní atributy souvisí s vnitřními faktory a jsou výraznými prediktory subjektivní pohody (Jovanovic, 2010). Z dlouhodobé perspektivy jsou osobnostní rysy spolehlivějším prediktorem spokojenosti než objektivní životní události² (Costa, McCrae, \& Zonderman, 1987; McCrae, \& Costa, 1991; Suh, Diener, \& Fujita, 1996; Hosseinkhanzadeh \& Taher, 2012). Analýza souvislostí mezi životní spokojeností a osobností byla nejprve směřována k temperamentovým vlastnostem, kdy se opakovaně prokázalo, že extroverti a emočně stabilní osoby jsou spokojenější se životem, než introverti a osoby emočně nevyrovnané (např. Costa \& McCrae, 1987; Blatný, 2005). V rámci analýzy studií věnujících se vztahům mezi životní spokojeností a osobnostními charakteristikami (v pojetí pětifaktorového modelu osobnosti) DeNeveové a Coopera (1998), se ukázalo, že životní spokojenost má nejsilnější vztah k emoční stabilitě a svědomitosti, nižší míra vztahu byla nalezena u extraverze a přivětivosti a nejslabší vztahy byly nalezeny u otevřenosti vưči novým zkušenostem. Detailnější vhled do vzájemných souvislostí mezi pětifaktorovým modelem osobnosti a životní spokojeností ukazuje, že extraverze souvisí s pozitivními emocemi a neuroticismus je spojen s negativními emocemi (Hills \& Argyle, 2001). Silným prediktorem pro kognitivní posouzení subjektivní pohody je svědomitost, přičemž některé ze studií naznačují, že se jedná o nejsilnější prediktor, který by mohl být vysvětlen snahou dosáhnout pokroku (DeNeve \& Cooper, 1998; Schimmack, Schupp, \& Wagner, 2008). Svědomití lidé mají tendenci usilovat o dosažení pohody (Boyce, Wood, \& Brown, 2010)

${ }^{2}$ Vnější události způsobují změny v mî́e životní spokojenosti, jen pokud se vymykají běžné životní zkušenosti a svou intenzitou překročí adaptační možnosti jedince. Po jejich odeznění, resp. po přizpůsobení se novým okolnostem, se osobní pohoda vrací na původní úroveň, determinovanou osobnostní výbavou (Blatný, 2005). 
a tíhnou k takovým životním stavům, které jsou pro životní spokojenost prospěšné (McCrae a Costa, 1991, Boyce \& Wood, 2011). Ačkoliv na obecné úrovni má svědomitost k životní spokojenosti pozitivní vztah, velmi závisí i na situačních proměnných, kdy za určitých okolností vysoká úroveň svědomitosti může působit opačně a životní spokojenost narušovat (ohrožovat) (Boyce, Wood, \& Brown, 2010). Přívětivost usnadňuje získání pozitivních zkušeností v sociálních situacích a tím zvyšuje míru životní spokojenosti (Hayes \& Joseph, 2002). Otevřenost vưči zkušenosti vede k touze (snaze) poznávat nové věci, které přináší uspokojení (viz McCare \& Costa, 1991; Stephan, 2009). Lidé s těmito charakteristikami pak vykazují pozitivní (vysokou) životní spokojenost, protože jsou zapojeni do činností, které uspokojují jejich psychologické potřeby (Stephan, 2009). Ukazuje se, že pětifaktorový model osobnosti umožňuje vysvětlit jednu třetinu variance v rámci životní spokojenosti (Wood, et al., 2008).

\section{3 Životní spokojenost a mladí dospělí}

Vzhledem k tomu, že studenti učitelských oborů se nachází v životní etapě mladé dospělosti, je podstatné poukázat na některé výzvy, které je v tomto období čekají a které mohou mít vliv na míru životní spokojenosti. Mladá dospělost je charakteristická mnoha souběžnými změnami ve všech aspektech života (Schulenberg, Bryant, \& O’Malley, 2004). Vyznačuje se vysokou mírou osobního rozvoje (Jessor, Donovan, \& Costa, 1991), značným zvýšením mobility a nezávislosti od rodičů a postupným přijímáním dospělých rolí (Erikson, 1968; Settersten, Fürstenberg, a Rumbaut, 2005). Jedná se o přechodné období, v němž se porovnávají hodnoty osvojené v dětství a soubor hodnot získaných v pozdějších obdobích. Mladí dospělí se musí přizpůsobit novému způsobu života, novým sociálním očekáváním a novým rolím. Potřebují objevit nové hodnoty, zájmy a postoje, směřující k těmto rolím (Erikson, 1968; Santos et al., 2014). Míra životní spokojenosti se objevuje společně s faktory spojenými s rozličným kontextem (např. osobnostní faktory, životní fáze (období), osobní hodnoty a jejich interpretace). Havighurst (1972) zdůraznil, že štěstí (nebo životní spokojenost) může mít základy v úspěšném dosažení konkrétní životní fáze v závislosti na vývojových úkolech vyplývajících ze tři zdrojů: fyzické zrání, kulturní tlak a individuální aspirace a hodnoty. V období rané dospělosti mohou vývojové úkoly zahrnovat nutnost či potřebu naučit se žít v partnerském vztahu, studia na vysoké škole, začátku profesní kariéry, případně založení rodiny (Bradley \& Corwyn, 2004). Tento proces nezbytně nutně vede ke změnám subjektivní pohody. Pokud bude jedinec při dosahování a zvládání vývojových úkolů mladé dospělosti úspěšný, Ize očekávat nárůst pocitů štěstí, životní úspěšnosti a spokojenosti (Martikainen, 2008; Santos et al., 2014).

\footnotetext{
3 Judge, Higgins, Thoresen \& Barrick (1999) v tomto smyslu doplňují, že pokud lidé odvozují životní spokojenost od úrovně př́immů, pak se výrazně uplatní právě osobnostní rys svědomitosti, který predikuje vyšší př́ijmy.
} 


\section{Metodologický rámec studie}

Předkládaný příspěvek je součástí širší výzkumné studie mapující problematiku vybraných psychosociálních faktorů ovlivňujících zdraví u budoucích učitelů. Obecným cílem je rozšíření poznatkové báze o specifické skupině studentů učitelských oborů. Lze předpokládat, že výsledky analýzy realizované na tomto souboru mohou přispět, prípadně podnítit modifikaci výukových postupů, přístupů a metod v rámci specializovaných psychologických předmětů vyučovaných na pedagogických fakultách. Konkrétním cílem této studie je analýza budoucích učitelů z hlediska jejich životní spokojenosti a její možné souvislosti s osobnostními proměnnými. $V$ tomto kontextu jsme stanovili následující výzkumné oblasti/otázky:

1. Komparovat jednotlivé oblasti životní spokojenosti u budoucích učitelů s normativními hodnotami.

2. Analyzovat vliv nezávislých proměnných pohlaví a věku na celkovou životní spokojenost.

3. Analyzovat souvislost mezi celkovou životní spokojenost a vybranými osobnostními charakteristikami u studentů učitelských oborů?

\subsection{Výzkumný soubor a výzkumné metody}

Výzkumný soubor je tvořen celkem 319 studenty učitelských oborů Univerzity Palackého v Olomouci. Konkrétně se jedná o 49 (15,4 \%) mužů a 270 (84,6 \%) žen. Prưměrný věk celého souboru je 22,4 let, Med (22), Mod (21), SD (4,14).

Výzkumná data směřující k naplnění výzkumných cílů byla ověřována na dvou standardizovaných dotaznících: Dotazník životní spokojenosti (DŽS) a NEO osobnostní inventář (NEO-PI-R).

\section{Dotazník životní spokojenosti}

\section{(DŽS, J. Fahrenberg, M. Myrtek, J. Schumacher, E. Brähler)}

Dotazník životní spokojenosti je určen k objektivnímu posuzování celkové životní spokojenosti a životní spokojenosti v deseti významných oblastech, které celkovou spokojenost utváří. Jedná se o následující oblasti (škály): Zdraví, Práce a zaměstnání, Finanční situace, Volný čas, Manželství a partnerství, Vztah k vlastním dětem, Vlastní osoba, Sexualita, Přátelé, známí, příbuzní a Bydlení, přičemž každá ze škál je sycena 7 položkami. Na jednotlivé položky dotazníků odpovídají respondenti na sedmibodové likertově škále. Do výpočtu Celkové životní spokojenosti (CS) se nezapočítává škála Práce a zaměstnání, Manželství a partnerství a Vztah k vlastním dětem (Rodná, Rodný, 2001). V kontextu tohoto příspěvku byla analyzována data pouze ve vztahu k Celkové životní spokojenosti (dále jen CS DŽS). 


\section{NEO osobnostní inventář (T. Costa, R. R. McCraee)}

Inventář představuje český překlad revidované verze NEO Personality Inventory (NEO-PI-R), která zjištuje pět obecných a široce pojatých dimenzí osobnosti: neuroticismus $(N)$, extraverzi $(E)$, otevřenost vůči zkušenosti $(O)$, přivětivost $(P)$ a svědomitost $(S)$. Pro měření každé škály je určeno 48 položek, inventář tedy celkem obsahuje 240 položek. Na položky inventáře se odpovídá na pětibodové Likertově škále.

Sběr dat probíhal v první polovině roku 2016 v rámci výuky, kdy byla studentům nabídnuta možnost aktivní účasti na výzkumném šetření. Studie byla realizována v souladu s etickými principy. Průzkumu se zúčastnili dospělí jedinci na základě dobrovolnosti. Každý účastník byl informován o možnosti ukončit účast v jakékoliv fázi bez udání důvodu. Všechna data byla zpracována anonymně, tak aby nebylo možné identifikovat konkrétní respondenty. Účastníci průzkumu souhlasili s anonymním zpracováním dat a jejich využitím pro vědecké účely. Administrace testové baterie byla realizována osobou s př́slušným psychologickým vzděláním a praxí.

\subsection{Výsledky}

V rámci analýzy dat byla nejprve vytvořena přehledová tabulka deskriptivní statistiky pro jednotlivé dimenze Osobnostního inventáře (NEO-PI-R) a Celkové skóre Dotazníku životní spokojenosti (CS DŽS) (viz Tab. 1).

Tab. 1

Deskriptivní statistika CS DŽS a NEO-PI-R

\begin{tabular}{|l|c|c|c|c|c|}
\hline & N & Minimum & Maximum & průměr & SD \\
\hline Neuroticismus & 319 & 4 & 52 & 24,41 & 8,273 \\
\hline Extraverze & 319 & 11 & 47 & 32,12 & 7,313 \\
\hline Otevřenost & 319 & 4 & 46 & 27,46 & 6,65 \\
\hline Př́ivětivost & 319 & 15 & 45 & 30,89 & 5,86 \\
\hline Svědomitost & 319 & 5 & 46 & 30,48 & 7,582 \\
\hline CS DŽS & 319 & 94 & 318 & 246,30 & 32,344 \\
\hline
\end{tabular}

Prvním zkoumaným tématem byla komparace průměrných hodnot jednotlivých škál dotazníku DŽS ${ }^{4}$ u budoucích učitelů s normativními hodnotami (graf 1). Jak je z grafu patrné, sledovaný soubor respondentů dosahuje ve srovnání s normami spíše mírně podprůměrných výsledků. Nejvíce jsou tyto rozdíly patrné u škály Zdraví a Vlastní osoba,

\footnotetext{
4 Do výpočtu Celkové životní spokojenosti (CS) se nezapočítává škála Práce a zaměstnání, Manželství a partnerství a Vztah k vlastním dětem.
} 
naopak u škály Bydlení jsou průměrné hodnoty respondentů vyšší, než jsou normativní hodnoty stejně starých respondentů v populaci.

\section{Graf 1}

Komparace průměrných hodnot škál dotazníku DŽS s normativními hodnotami.

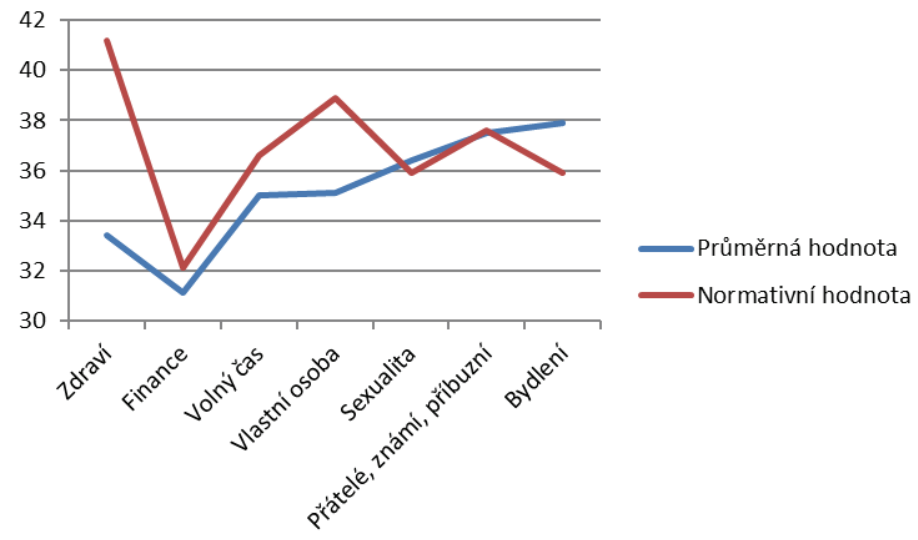

Dále byla sledována souvislost mezi pohlavím a životní spokojeností (CS DŽS) a věkem a životní spokojeností (CS DŽS). V obou prípadech nebyla neprokázána signifikantní souvislost mezi sledovanými jevy. Spearmanova korelace neprokázala signifikantní souvislost mezi pohlavím a CS DŽS $(r=0,02)$, ani mezi věkem a CS DŽS $(r=-0,008)$.

Poslední zkoumanou oblastí byla analýza souvislostí mezi celkovou životní spokojeností (CS DŽS) a osobností (NEO-PI-R). Z Tab. 2 je patrné, že byla potvrzena signifikantní souvislost mezi celkovou životní spokojeností (CS DŽS) a Extraverzí $(r=0,37)$, Prívětivostí $(r=0,3)$ a Svědomitostí $(r=0,23)$. Negativní vztah byl potvrzen v prípadě škály Neuroticismu $(r=-0,49)$. Naopak u škály Otevřenost $(r=0,04)$ nebyla prokázána signifikantní souvislost s celkovým skórem životní spokojenosti.

\section{Tab. 2}

Spearmanova korelace mezi Celkovým skórem DŽS a jednotlivými škálami NEO-PI-R

\begin{tabular}{|c|c|c|c|c|c|}
\hline & Neuroticismus & Extraverze & Otev̌renost & Prívětivost & Svědomitost \\
\hline CS DŽS & $-0,49^{*}$ & $0,37^{*}$ & 0,04 & $0,3^{*}$ & $0,23^{*}$ \\
\hline
\end{tabular}

$p=0,05$ 


\section{Diskuze a závěry}

Zkoumání životní spokojenosti má v psychologii dlouhodobou tradici, přičemž význam tohoto tématu stále vzrůstá. Životní spokojenost je sycena celou řadou faktorů (osobnost, postoje, hodnoty atd.) a tvoři ji množství aspektů či oblastí běžného života. Míra životní spokojenosti pak společně s dalšími faktory ovlivňuje postoj jedince ke světu i k sobě samému. Z hlediska vysokoškolských studentů, konkrétněji studentů učitelských oborů, je sledování životní spokojenosti významné nejen na úrovni vztahující se k jedinci samotnému, ale především na úrovni vztahující se k budoucí učitelské profesi a kvalitě jejího výkonu. Ačkoliv je životní spokojenost v některých aspektech vázána na vrozené faktory, jsme přesvědčeni, že existuje relativně dostatečně velký prostor k možnostem jejího ovlivnění a osvojení si některých postupů, technik či metod v rámci výuky specializovaných psychologických předmětů realizovaných na pedagogických fakultách, umožňujících její snazší naplňování.

Výsledky z našeho výzkumu naznačují, že životní spokojenost studentů učitelských oborů je ve srovnání s normativními hodnotami mírně podprůměrná, a to v pěti, ze sedmi sledovaných oblastí (viz Tab 2). Nejvíce se rozdíly průměrných hodnot ukázaly v oblastech vztahu k vlastní osobě a zdraví, nejméně pak u kategorie bydlení. Vysokoškolští studenti jsou výrazně více subjektivně nespokojení se svým zdravím ve srovnání se stejně starými vrstevníky, stejně tak i ve srovnání se skupinou současných učitelů (srov. Sigmund, Kvintová, Pugnerová, Hřebíčková, 2014). Tuto diskrepanci, stejně tak i nižší spokojenost s vlastní osobou, považujeme za zajímavá zjištění. Je tedy zřejmé, že by této problematice měla být věnována zvýšená pozornost.

Řada studií sledovala při zkoumání aspektů životní spokojenosti i vliv demografických faktorů (především věku a pohlaví), prič̌emž dlouhodobě se ukazují spíše protichůdné výsledky a nelze zcela jednoznačně posoudit, zda či případně jaký vliv má faktor věku či pohlaví na sledovanou nezávislou proměnnou. Lze však očekávat, že s přibývajícím věkem se bude celková životní spokojenost mírně zvyšovat (Ryff, \& Keyes, 1995; Fahrenberg, et al., 2001). V prípadě naší studie se ukázalo, že ani jeden ze sledovaných demografických faktorů s životní spokojeností nesouvisí. Celý výzkumný soubor se $v$ zásadě pohybuje ve vývojovém období mladší dospělosti a vzhledem $k$ tomu, že se navíc jedná o relativně homogenní skupinu tvořenou studenty humanitního zaměření, i ve světle získaných výsledků Ize soudit, že respondenti sledují stejné/podobné životní cíle, získávají obdobné životní zkušenosti, prochází podobnými změnami a čelí i podobným životním výzvám (viz např. Erikson, 1968; Schulenberg, Bryant, \& O'Malley, 2004; Settersten, Fürstenberg, a Rumbaut, 2005). Př́padné rozdíly ve struktuře životní spokojenosti, respektive jejich jednotlivých složkách a její celkové míře pak pravděpodobně budou, $v$ rámci sledovaného souboru respondentů, souviset $s$ jinými faktory (např. osobnostní či hodnotovou orientací). 
Z hlediska pohlaví, je třeba brát v úvahu relativně málo početné zastoupení mužů ve sledovaném vzorku respondentů. Rovněž lze vzít v úvahu i faktor věku. Při přechodu $z$ adolescence do mladé dospělosti dochází do určité míry i ke změně pojetí mužské a ženské role $v$ souvislosti s odlišnými nároky, očekáváními a úkoly, které jsou na jednotlivce kladeny (viz např. Erikson, 1968; Santos, et al., 2014). Mladí dospělí si tedy teprve osvojují své ženské/mužské role v dospělém věku a učí se s nimi „,pracovat", což může být jeden z důvodů, proč nebyla zjištěna souvislost mezi pohlavím a životní spokojeností. V neposlední řadě považujeme za důležité zmínit i použitou metodu, která vnímá životní spokojenost jako výslednici dílčích spokojeností v jednotlivých životních oblastech (podrobněji viz výše). Je tedy možné, že při použití odlišné diagnostické metody posuzující životní spokojenost v jiném kontextu, by byla souvislost s pohlavím prokázána. Tento předpoklad do určité míry potvrzuje i fakt, že u výzkumů, které souvislost mezi pohlavím a životní spokojeností prokázaly, byly použité odlišné metody (např. Wood et al., 1989; Boarini et al., 2012). Samožrejmě nelze vyloučit ani možnost, že mezi pohlavím a životní spokojeností souvislost není, což koneckonců zmiňují i někteři jiní výzkumníci (např. Fahrenberg, et al., 2001).

Poslední sledovanou oblastí byla analýza souvislostí mezi celkovou životní spokojeností a osobností. $V$ rámci této části studie se ukázaly velice podobné výsledky jako u většiny jiných studií realizovaných prostřednictvím stejné metody diagnostiky osobnosti (dotazníky vycházející z tzv. modelu Big Five). Potvrdili jsme, že životní spokojenost má nejsilnější vztah k emoční stabilitě, extraverzi a přivětivosti a v nižší míre vztahu i ke svědomitosti (srov. např. DeNeve \& Cooper, 1998; Hayes \& Joseph, 2002; Schimmack, Schupp, \& Wagner, 2008; Boyce, Wood, \& Brown, 2010).V prípadě škály otevřenost vůči novým zkušenostem nebyla v našem případě souvislost prokázána, zatímco u srovnávaných studií se vzájemné vztahy projevily, ač byly nejslabší ze všech sledovaných (McCare \& Costa, 1991; Stephan, 2009). Uvedené zjištění považujeme za překvapivé, nebot', jak uvádí např. McCare a Costa (1991) nebo Stephan (2009), otevřenost vůči zkušenosti vede k touze poznávat nové věci, které přináší uspokojení. Souvislost této osobnostní charakteristiky s životní spokojeností bychom právě u vysokoškolských studentů očekávali. V tomto smyslu tyto výsledky vnímáme jako zajímavé a nosné pro další výzkumné směřování. Celkově se však potvrzuje fakt, že osobnost je velice silný prediktor životní spokojenosti.

Limity předkládané studie spatřujeme především v následujících bodech a) využití dotazníkové metody ( $v$ kontextu obecných nevýhod dotazníkových metod jako takových), b) relativně malý výzkumný soubor a disproporční zastoupení v rámci pohlaví (uvedené však odpovídá demografickému rozložení studentů pedagogických fakult a je tedy možné jej považovat v tomto kontextu za normální), c) výzkumný soubor je tvořen studenty pouze jedné pedagogické fakulty a v tomto smyslu se tedy zúží aplikační možnosti výsledků. 


\section{Závěr}

V rámci studie se neprokázala souvislost životní spokojenosti s věkem a pohlavím. Byly potvrzeny výsledky dřívějších výzkumných studií zabývajících se souvislostmi mezi životní spokojeností a osobností. Konkrétně se potvrdila vazba mezi životní spokojeností a emoční stabilitou, extraverzí, př́ivětivostí a svědomitostí. Naopak nebyla prokázána souvislost životní spokojenosti s otevřeností vůči novým zkušenostem. U studentů učitelských oborů byla zjištěna výrazně nižší míra spokojenosti se zdravím a vlastní osobou, než jsou normativní hodnoty stejně staré populace. Výsledky studie tedy přinesly nejen potvrzení očekáváných výsledků, ale i některé nové poznatky (viz výše) o sledované problematice. Tyto považujeme z hlediska budoucích výzkumných snah za přínosné, a to nejen vzhledem ke specifické skupině vysokoškolských studentů učitelských oborů, ale i k potenciálním možnostem modifikování výukových postupů, přístupů a metod v rámci specializovaných psychologických předmětů vyučovaných na Pedagogických fakultách.

Tato studie vznikla s podporou projektů: Grantový fond děkana PdF UP: Rizikové a protektivní faktory u učitelů v pregraduální prípravě. Projekt IGA_PdF_2016_020 Vybrané psychosociální faktory ovlivňující zdraví u současných vysokoškolských studentů učitelských oborů.

\section{Literatura}

Barker, C., \& Martin, B. (2009). Dilemmas in teaching happiness. Journal of University Teaching and Learning Practice, 6(2), 1-14.

Blatný, M. (2001). Osobnostní determinanty sebehodnocení a životní spokojenosti: mezipohlavní rozdíly. Československá psychologie, 45(5), 385-392.

Blatný, M. (2005). Osobnostní předpoklady sebehodnocení a životní spokojenosti: shody a rozdíly. In: M. Blatný (Ed.), Psychosociální souvislosti osobní pohody (s. 83-107). Brno: Masarykova univerzita.

Boarini, R., Comola, M., Smith, C., Manchin, R., \& de Keulenaer, F. (2012). What Makes for a Better Life? The Determinants of Subjective Wellbeing in OECD Countries - Evidence from the Gallup World Poll. OECD Statistics Working Papers, 2012/03, OECD Publishing. Dostupné z: http://www. oecd-ilibrary.org/economics/what-makes-for-a-betterlife_5k9b9ltjm937-en

Boyce, C. J., Wood, A. M., \& Brown, G. (2010). The dark side of conscientiousness: Conscientious people experience greater drops in life satisfaction following unemployment. Journal of Research in Personality, 44, 535-539.

Boyce, C. J., \& Wood, A. M. (2011). Personality prior to disability determines adaptation: Agreeable individuals recover lost life satisfaction faster and more completely. Psychological Science, 22, 1397-1402.

Bradley, R. H., \& Corwyn, R. F. (2004). Life satisfaction among European American, African American, Chinese American, Mexican American, and Dominican American adolescents. International Journal of Behavioral Development, 28(5), 385-400,

Costa, P. T. Jr., Zonderman, A. B., McCrae, R. R., Cornoni-Huntley J., Locke, B. Z., Barbano, \& H. E. (1987). Longitudinal analyses of psychological well-being in a national sample: stability of mean levels. The Journal of Gerontology, 42(1), 50-55. 
Darling-Hammond, L. (1999). Teacher quality and student achievement: A Review of state policy evidence. Seatle, WA: Center for the Study of Teaching and Policy, University of Washington.

DeNeve, K. M., \& Cooper, H. (1998). The happy personality: A metaanalysis of personality traits and subjective well-being. Psychological Bulletin, 124, 197-229.

Diener, E. (1984). Subjective well-being. Psychological Bulletin, 95, 542-575.

Diener, E., Suh, E., \& Oishi, S. (1997). Recent findings on subjective well-being. Indian Journal of Clinical Psychology, 24, 25-41.

Diener, E. (2000). Subjective Well-Being. The Science of Happiness and a Proposal for a National Index. American Psychologist, 55(1), 34-43.

Erikson, E. H. (1968). Identity, youth and crisis. New York: W. W. Norton Company.

Fahrenberg, J., Myrtek, M., Schumacher, J. \& Brähler, E. (2001). Dotazník životní spokojenosti. Praha: Testcentrum.

Hamplová, D. (2004). Životní spokojenost: rodina, práce a další faktory. Praha: Sociologický ústav.

Hayes, N., \& Joseph, S. (2002). Big 5 correlate of three measures of subjective well-being. Personality and Individual Differences, 34, 723-727.

Havighurst, R. J. (1972). Developmental Tasks and Education. New York: McKay.

Hills, P., \& Argyle, M. (2001). Emotional stability as a major dimension of happiness. Personality and Individual Differences, 31(8), 1357-1364.

Hosseinkhanzadeh, A. A., \& Taher, M. (2013). The Relationship between Personality Traits with Life Satisfaction. Sociology Mind, 3(1), 99-105.

Hřebíčková, M. (2004). NEO osobnostní inventář. Praha: Testcentrum.

Huang, H. (2005). The Relationships between Demographic Variables, Playfulness, Motivation of Teaching, Happiness and Creative Teaching among Junior High School Teachers. [on-line]. 2005 [cit. 2016-11-02]. Dostupné z: http://etd.lib.nsysu.edu.tw/ETD-db/ETD-search/view_ etd?URN=etd-0628106-094049.

Jessor, R., Donovan, J. E. \& Costa, F. M. (1991). Beyond Adolescence. Cambridge: Cambridge University Press.

Jovanovic, V. (2010). Personality and subjective well-being: One neglected model of personality and two forgotten aspects of subjective well-being. Personality and Individual Differences, 50, 1-5.

Judge, T. A., Higgins, Ch. A., Thoresen, C. J., \& Barrick, M. R. (1999). The big five personality traits, general mental ability, and career success across the life span. Personnel Psychology, 52(3), 621-652.

Kebza, V., \& Šolcová, V. (2005). Koncept osobní pohody (well - being) a jeho psychologické a interdisciplinární souvislosti. In M. Blatný (Ed.), Psychosociální souvislosti osobní pohody (s. 11-35). Brno: Masarykova univerzita.

Křivohlavy, J. (2001). Psychologie zdraví. Praha: Portál.

Mareš, J. (2001). Pozitivní psychologie: důvod k zamyšlení i výzva. Československá psychologie, 45, 97-117.

Martikainen, L. (2008). The Many Faces of Life Satisfaction among Finnish Young Adults'. Journal of Happiness Studies, 10(6), 721-737.

McCrae, R. R., \& Costa, P. T. (1991). Adding Liebe und Arbeit: The Full Five-Factor Model and WellBeing. Personality and Social Psychology Bulletin, 17(2), 227-232.

Muijs, D., \& Reynolds, D. (2005). Effective teaching. Evidence and practice. London: SAGE Publications Ltd.

Noddings, N. (2005). Identifying and responding to needs in teacher education. Cambridge Journal of Education, 35(2), 147-159.

Ripski, M. B., LoCasale-Crouch, J., \& Decker, L. (2011). Pre-service teachers: Dispositional traits, Emotional states, and quality of teacher-students interaction. Teacher Education Quarterly, 38(2), 77-96. 
Ryff, C. D. \& Keyes, C L. (1995). The structure ofpsychological well-being revisited. Journal of Personality and Social Psychology, 69,719-727.

Řehulková, O., \& Řehulka, E. (2008). Otázky kvality života na základě předchozích výzkumů. In Řehulka, O. Řehulková, \& M. Blatný (Eds.), Kvalita života v souvislostech zdraví a nemoci. Brno: MSD, s. 16-30.

Seligman, M. E. P., \& Csikszentmihalyi, M. (2000). Positive psychology: An introduction. American Psychologist, 55, 5-14.

Settersten, R. A., Fürstenberg, F. F. \& Rumbaut, R. C. (2005). On the Frontier of Adulthood. Theory, Research, and Public Policy. Chicago: University of Chicago Press.

Santos, M. C. J., Magramo, C. S., Oguan, F. \& Paat, J. N. (2014). Establishing the relationship between general selfefficacy and subjective well-being among college students. Asian Journal of Management Sciences \& Education, 3(1), 1-12.

Schimmack, U., Schupp, J., \&Wagner, G. G. (2008). The influence of environment and personality on the affective and cognitive component of subjective well-being. Social Indicators Research, 89, 41-60.

Schulenberg, J. E., Bryant, A. L., \& O'Malley, P. M. (2004). Taking hold of some kind of life: How developmental tasks relate to trajectories of well-being during the transition to adulthood. Development \& Psychopathology, 16, 1119-40.

Sigmund, M., Kvintová, J., Pugnerová, M., \& Hřebíčková, H. (2014). Comparison of Live Satisfaction and ITS Components in Current Teachers and Selected Profession GROUPS. e-Pedagogium. An independent scientific journal for interdisciplinary research in pedagogy, 4, pp. 104-122.

Spilt J. L., Koomen, H. M. Y., \& Thijs, J. T. (2011). Teacher Wellbeing: The Importance of Teacher Student Relationships. Educational Psychology Review, 23(4), 457-477.

Stepan, Y. (2009). Openness to experience and active older adults' life satisfaction a trait and facet-level analysis. Personality and Individual Differences, 47, 637-641.

Suh, E., Diener, E., \& Fujita, F. (1996). Events and Subjective Weil-Being: Only Recent Events Matter. Journal of Personality and Social Psychology, 70(5), 1091-1102.

Thornton, H. (2006). Dispositions in Action: Do dispositions make a difference in practice? Teacher Education Quarterly, 33(2), 53-69.

van Veen, K., Sleegers, P., \& van de Ven, P. H. (2005). One teacher's identity, emotions, and commitment to change: A case study into the cognitive-affective processes of a secondary school teacher in the context of reforms. Teaching and Teacher Education, 21, 917-934.

Wenzlaff, T. (1998). Dispositions and portfolio development. Is there a connection? Education, 118(4), 564-573.

Wood, W., Rhodes, N., \& Whelan, M. (1989). Sex Differences in Positive Well-Being: A Consideration of Emotional Style and Marital Status. Psychological Bulletin, 106(2), 249-264.

Wood, A., Joseph, S., \& Maltby, J. (2008). Gratitude uniquely predicts satisfaction with life: Incremental validity above the domains and facets of the five factor model. Personality and Individual Differences, 45, 49-54.

Yuan, O. S., \& Aman, R. Ch. (2016). The dominant big five personality among pre-service teachers in theteacher education institutes (ipgm) in malaysia. Proceeding of ICECRS, 1, 1-11.

\section{Kontakt:}

Mgr. Lucie Křeménková, Ph.D.

PhDr. Jana Kvintová, Ph.D.

Mgr. Michaela Pugnerová, Ph.D.

Katedra psychologie a patopsychologie

Pedagogická fakulta, Univerzita Palackého v Olomouci

Žižkovo náměstí 5, Olomouc 77140

E-mail: lucie.kremenkova@gmail.com; jana.kvintova@upol.cz; michaela.pugnerova@upol.cz. 